\title{
MOTIVATING ENGLISH TEACHERS BASED ON THE BASIC NEEDS THEORY AND AN EXPECTANCY THEORY
}

\author{
Hidayatus Sholihah \\ Universitas Islam Sultan Agung \\ Semarang, Indonesia \\ hida@unissula.ac.id
}

\begin{abstract}
There are two main motivation theories: a hierarchy of basic needs theory and an expectancy theory. In a Hyrarchy of basic needs theory, Maslow has stated that the basic needs as a main behaviour direction are structured into a hierarchy. There are five basic human needs. The first: Physiological needs such as: salary, bonus or working condition. The second: the safety needs, such as: safe job environment, job security or health cover. The third, social needs, such as union and team work. The next is self esteem, such as getting an award, medal, certificate or any other recognisition. Then the last is self actualization, for example is by providing an opportunity to share knowledge, skills and eprerience. The evaluation of this theory are: there is no spiritual needs as human basic needs is a main weakness of this theory. Then it is possible that different level of needs have to be satisfied in the same time, or not in hierarchy level or, not always have to be fulfilled in order. The next motivation theory is an Expectancy Theory. This theory is based on three main factors. The first factor is: English teachers will be motivated to work harder if they have a good perception to their own competences in accordance with their job. The second, individual motivation depends on the rewards given when they finish a particular job. Finally, it also depends on their regards to the rewards given from the job that they do. Expectancy theory is a good theory, however, it is not easy to be implemented because the principals should provide various types of reward to satisfy the expectation of their English teachers. Considering the strengths and weaknesses of these two theories, it is better to combine both of them in the practice to get more effective results.
\end{abstract}

Keywords: Motivation, reward, English teachers

\section{INTRODUCTION}

Motivation is a common term and has already been familiar for centuries. It is an essential factor which can improve productivity. The higher motivation that English teachers have, the more productive they will be. English teachers tend to work harder if they have a good motivation. Therefore, unmotivated English teachers are likely to be unproductive. 
Because of that reason, principals nowadays use motivation as a key word to improve their English teachers' productivity. Without a good motivation, English teachers would be in the bottom level of productivity, whereas with the highest motivation, they would be very productive English teachers.

\section{DISCUSSION}

There are several definitions of motivation. Petri (1991) defines motivation as 'the force acting on or within an organism to initiate and direct behaviour', or it is 'the direction of behaviour'. It is also defined as "the influence or drive that causes people to behave in a specific manner" (Korth cited in Gilley, Gilley, \& McMillan, 2009). Therefore, based on several definitions above, motivation may be defined as the force that drive, direct and energize people to behave in certain manner.

Motivation is crucial because it is needed to encourage, inspire and stimulate English teachers to reach the best accomplishments (Peterson, 2007). It is also important for improving English teachers' productivity, because the higher motivation that English teachers have, the more productive they will be (Pardee, 1990). One of the examples is when English teachers are tired with their job load, they can still keep working after short break or taking rest, when they are not in a good mood, they direct themselves to keep teaching as good as possible if they have a good motivation.

Motivation has a function as a motor energizing people to do their task. It is also a direction of behaviours to realize and reach the goals and ideals. So, it can select and decide which behaviour relevant with our goal by neglacting which are not useful for reaching our goal and which one that supporting our goal.

Another word which is quite common related to motivation is a 'reward'. The meaning of the reward here is 'something given in return for work or services' (Oxford, 1995). The main purpose of giving it is to motivate English teachers to work harder, or increase their productivity. 
Sholihah, Motivating English Teachers Based On The Basic Needs Theory...

As we know that there are two types of motivation, an extrinsic, and an intrinsic motivation. The extrinsic motivation is the motivatation that comes from outside - those who are motivated when they got a reward from other people for example. Several English teachers are motivated by a reward as an extrinsic motivation to improve their productivity. However, others might not be motivated by it. In addition, an intrinsic motivation is the motivation that comes from inside such as: a big dream, vision or goal that can motivate English teachers to work harder, smarter and better. In the following, it is going to discuss two mains motivation Theories.

Motivation Theories

There are several major theories about motivation. This essay will discuss and analyse motivation based on a hierarchy, and an expectancy theories, then evaluate those theories.

Two Major Motivation Theories

1. The Hierarchy of Needs Theory

According to Maslow (1987), basic needs as a main behaviour direction, what motivate English teachers, are structured into a hierarchy. When English teachers can satisfy their first basic needs, physiological needs, then they will be motivated to fulfil the higher level needs. It is illustrated by the following picture.

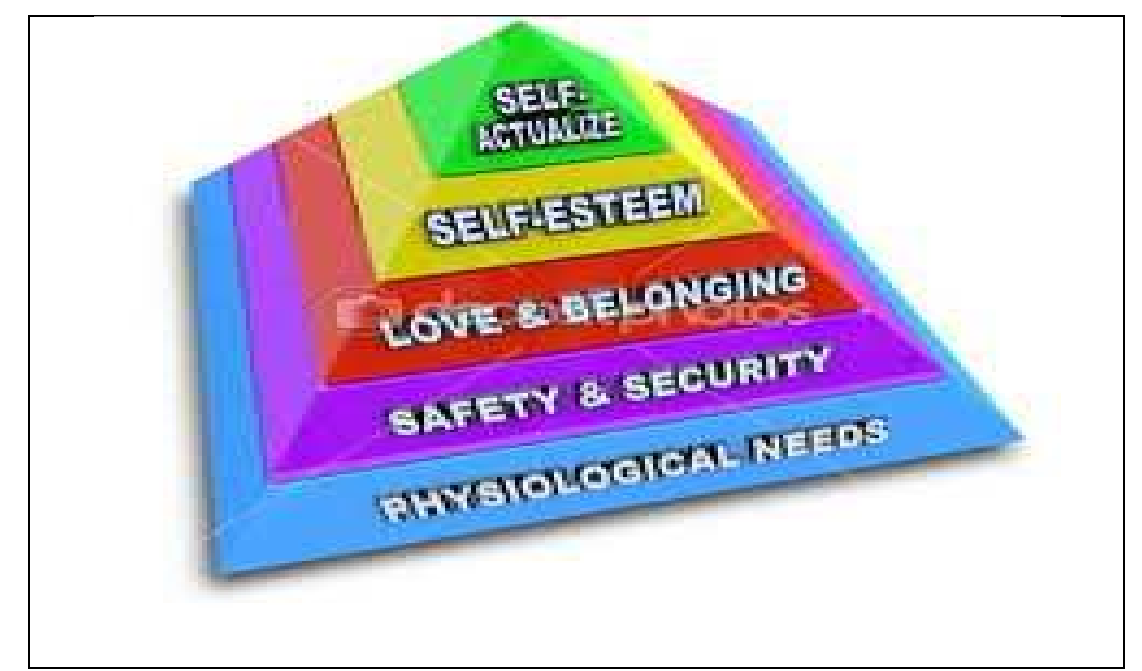

Figure 1: Maslow's pyramid (picture source: www.google.com) 
There are five basic human needs. The most basic need is physiological needs, here is related to human body needs such as eating food and drinking water. It is the most important need for human compare with other needs, especially in the place where someone lacks of food or water to drink.

The next level of needs, the safety needs such as: security, protection, and freedom from fear. In a modern world, we can find the safety needs expressed by preferring to get a job provided protection, buying goods which provide warranty, taking various insurance, such as: medical, disability, and old age insurance.

Social needs are the following needs to be satisfied. English teachers need love from others, they also need to express their love to others. They also needs to interact and help each other. Their social needs also can be satisfied by an active member of English teachers' communities, clubs or organisations, where English teachers in the developed world can easily get friends with the same interest or hobbies nowadays. So, their social needs can be satisfied and their feelings of loneliness, alienation can be overcome.

All English teachers have desire for respect whether from themselves or from other English teachers. There are two classifications of esteem needs. First, it is related to their self respect such as: the desire to have independence, a confidence, mastery and a competence in their job. Second is the respect from other people especially who deal with them, such as prestige or reputation, dignity, attention, and appreciation.

Self actualization is the fifth or the top level of needs after all of the basic needs above are satisfied. For example, English teachers want to teach, researchers want to conduct research, musicians want to make music. So, it is a tendency for them to actualize their potential (Maslow, 1987).

According to the hierarchy theory, the rewards which can motivate English teachers to work better depend on the level of English teachers' needs. Therefore, principals as managers should understand well about the condition of their English teachers in order to be able to motivate them effectively. 
Sholihah, Motivating English Teachers Based On The Basic Needs Theory...

There are five types of rewards in accordance with the hierarchy theory. First of all, English teachers who are still at the bottom level of needs (physiological needs) will be motivated by salary, bonus or working condition. Therefore, increasing salary, giving bonus or providing comfortable working condition can be a tool to motivate English teachers to improve their productivity. However, for English teachers whose physical needs have been fulfilled, it is not effective anymore to encourage them to work better by giving bonus, or increasing their salary. So the best type of reward for these English teachers who are in the next level of basic needs (safety needs) is by providing safe job environment, job security or health cover.

The next is, for English teachers who are in the middle level of basic needs (social needs), developing a harmony relationship with others is a very important thing. So, working with the teams is a good way to motivate them to perform better.

The following type of rewards for English teachers whose needs of self esteem emerge is by giving them positive feedback which can improve their self esteem, or by recognition such as giving award for their best job, or giving recognition for their achievement at work by holding a celebration party or announced on the regular ceremony.

The last type of reward appropriate for English teachers who are at the top level of basic needs is by giving them a space to create something based on their field or by giving a challenging job. By doing so, they will be motivated to work harder (Halepota, 2005).

Maslow's theory is a good theory because it gives us information about two main aspects within human being, physiological and psychological needs that can motivate English teachers. He also treats human as a unique individual who has different needs. However, we still found weaknesses of this theory.

This theory generalize a type of reward for English teachers who are at the same level of basic needs. Whereas, not all English teachers have the same 
interest in the types of rewards although they are at the same position. For example, in a school where English teachers are in the level of physiological needs, several English teachers are interested in the increasing salary as the reward. Others might increase their productivity in order to get promotion, or bonus.

If principals generalize their English teachers and give the same rewards, therefore it will be not effective to motivate them. In addition, it is possible that different level of needs have to be satisfied in the same time, or not in hierarchy level. For example, English teachers may need a good wage, safety, and a good team work at the same time in order to improve their productivity. If one of those needs is not fulfilled, they may not be productive.

Moreover, it is possible that English teachers, who are still in the battom needs of a hierarchy needs theory, have a good motivation to work if they have a good relationship with their colleagues although their salary is still low. So, it is possible that English teachers can jum up to the third level of the basic need in the Hierarchy need theory without satisfying their bottom need in advance. Therefore, it the needs are not always have to be fulfilled in order, as stated by the theory.

In addition, Neher (1991) finds that, in some cases, Maslow's theory does not work. One example is in the case of creative English teachers. They need self actualization more than the other needs although they may still in the bottom level of needs, physiological needs. Therefore, motivating these English teachers by satisfying their basic needs based on their position level of Hierarchy may not be successful.

Furthermore, Maslow does not mention about spiritual needs as human basic needs in his theory. Although all of their physiological, and psychological needs are satisfied, English teachers may be unmotivated to work more productive if they do not have opportunity to conduct their ritual or religious obligation, or their places of work do not provide facilities such as a private room for conducting prayer. 
Sholihah, Motivating English Teachers Based On The Basic Needs Theory...

In Indonesian context, spiritual need should be placed on the top of the Hierarchy needs because in fact, some English teachers in Indonesia might have spirit or motivation to teach persistently because their spiritual need is fulfilled well. Some English teachers work hard although they do not have a good salary, and they are still unwalfare because they are motivated by their religion lesson that teach them to work as a apart of worshiping God. For them, teaching is not simply because of material matters.

Based on the evaluation on the Maslows' theory above, the Hierarchy needs theory, this theory can not be taken by granted or can not totally be applied without considering about it's weaknesses.

In order to be able to motivate and improve teacher's productivity effectively, several evaluations of the theory should be considered well. The main points of the evaluation on the Maslow's theory are the principals absolutetely can still apply this theory by underlining the uniqness of teacher's character and their interest, for example in prefering their rewards. The consequences of this, the English teachers' needs are not always in order or in a hierarchy. Then, principal should also consider the English teachers' spiritual needs in motivating them. By doing so, the prinsipal as a manager, hopefully, can motivate effectively English teachers to be more productive.

\section{An Expectancy Theory}

Room, Porter and Lawler in Cascio (1995) introduced the expectancy theory which can be a complement to Maslow's theory. If Maslow constructed his theory based on physical and psychological needs as something which can motivate English teachers, Victor Room formulated a theory which gives important information for principals to know how to motivate their English teachers. This theory is based on three main factors.

The first factor is: English teachers will be motivated to work harder if they have a good perception to their own competences in accordance with their job. So, in reverse, if they have low perception regarding their capability to do 
their job, they will be unmotivated. Usually, the more interesting rewards will lead to the better perception. The second, individual motivation depends on the rewards given when they finish a particular job. Finally, it also depends on their regard to the rewards given from the job that they do. The higher value they give to the rewards, the more it can motivate them to be more productive.

Therefore, whatever the rewards are, they will be unvaluable if they do not match their expectations. For example, for one teacher, a bonus is a valuable reward, but it may be meaningless reward for other English teachers who may expect promotion as a structural leader. In this case, bonus can motivate the teacher to do extra efforts but it cannot motivate the other to work harder. Different English teachers have different expectation about reward, and they cannot be motivated by the same reward. So, it is important to know what English teachers think about rewards given because their opinions about the value of rewards will influence their motivation (Cascio, 1995).

Room in the expectancy theory has stated that English teachers' motivation depends on their perception related to their job, reward, and their regard to the rewards (Halepota, 2005). Because this motivation theory based on English teachers' perception, different English teachers will have different perception. It means that different English teachers have different thing which can motivate them. Therefore, the types of the rewards for English teachers in order to work harder based on this theory are various depend on an individual perception. For example, for one teacher holiday trip as a bonus is interesting and it can motivate him / her, but for another teacher it may not be attractive and cannot motivate them to increase their job performance.

Expectancy theory is a good theory. However, it is not easy to be implemented because of two main reasons. The first, different people has different interest. This means that principals should understand well about the expectation of each teacher before deciding to give reward to them, and this may be difficult to be applied in a big schools or institutions which have 
Sholihah, Motivating English Teachers Based On The Basic Needs Theory...

many English teachers. The Second, the principals should provide various types of reward to satisfy the expectation of their English teachers if they want to motivate them based on their expectation and perception. Applying this theory to motivate teacher to work harder may spend much more time and effort.

Considering the strengths and weaknesses of these two theories, it is better to combine both of them in the practice to get more effective results. Principals have to investigate what motivate their English teachers based on Maslow's theory, then they have to decide how to motivate them based on expectancy theory. Having understanding about their English teachers' level of needs, principals have to investigate each teacher's expectation of reward, and finally they can decide to give the best rewards to motivate their English teachers effectively.

\section{CONCLUSION}

Maslow (1987) formulates a hierarchy theory of motivation about what motivate people, while expectancy theory consists of the way, how to motivate people. Based on the hierarchy theory, types of rewards to motivate English teachers to be more productive are in accordance with the level of basic needs. Moreover, according to Room (in Cascio, 1995), rewards given should be matched with the expectation of people. Each theory has strengths and weaknesses. Therefore, it is very good to apply those theories by combining both of them in the practice in order to get more effective result.

\section{REFERENCES}

Cascio, W.F. (1995). Managing human resource: productivity, quality of work life, profits, 4th edn, McGraw-Hill, Inc, USA. 
Compiler, C \& Manser, MH (1991). Oxford learner's pocket dictionary, New York: Oxford University Press.

Gilley, A., Gilley, J. W., \& McMillan, H. S. (2009). Organisational change: Motivation, communication, and leadership effectiveness. Performance Improvement Quarterly, 21(4), 75-94.

Halepota, H.A. (2000). Motivational theories and their application in construction', Cost Engineering Journal, vol. 4, no. 3, pp. 15-16, viewed 29 June 2009, (Proquest)

Maslow, A.H. (1987). Motivation and personality, 3rd ed. New York: Hamper \& Row Inc.

Neher, A. (1991). Maslow's Theory of Motivation: A critique. Journal of Humanistic Psychology, 31(89).

Petri, H.L. (1991). Motivation: theory, research, and applications, 3rd ed., California: Wadsworth Publishing Company. 